\title{
Las imágenes de Rostros y Lugares (2017). Una reflexión desde el documental performativo y los estudios visuales
}

\author{
The images of Faces Places (2017). A reflection from the \\ performative documentary and the visual studies
}

\author{
Fabiola Alcalá Anguiano \\ Universidad de Guadalajara, México \\ f.alcala79@gmail.com \\ https://orcid.org/0000-0002-1200-280X
}

\begin{abstract}
Resumen:
En este texto se analiza la película Rostros y Lugares de la cineasta Agnès Varda y del artista gráfico JR (2017) tomando en cuenta su condición de documental performativo y siguiendo algunas pautas teórico-metodológicas que los estudios visuales como campo y como método ofrecen. Este análisis permite reflexionar sobre las funciones emotiva y reflexiva de las imágenes, ya sean fotográficas, cinematográficas, de gran formato, analógicas o digitales. Así como en su repercusión estética y sociopolítica siguiendo los aportes de Bill Nichols, Nicholas Mirzoeff y Gille Deleuze.

El análisis se divide en cuatro tipos de imágenes que ayudan a comprender cómo funciona narrativa y estéticamente el filme, un documental que además está constituido por instalaciones fotográficas y por sus réplicas en internet, estas son: imágenes instalación, imágenes introspección, imágenes ausencia e imágenes reproducción, una taxonomía en construcción que puede servir de base para el estudio de otros filmes de esta naturaleza.
\end{abstract}

\section{Abstract:}

In this text, the film Faces Places by the filmmaker Agnès Varda and the graphic artist JR (2017) is analyzed, taking into account his condition as a performative documentary and following some theoretical-methodological guidelines that visual studies as a field and as a method offer. This analysis allows us to reflect on the emotional and reflexive functions of images, whether photographic, cinematographic, large format, analog or digital. As well as its aesthetic and sociopolitical impact following the contributions of Bill Nichols, Nicholas Mirzoeff and Gille Deleuze. The analysis is divided into four types of images that help to understand how the film works narratively and aesthetically, a documentary that is also made up of photographic installations and their replicas on the internet, these are: installation images, introspection images, absence images and images reproduction, a taxonomy under construction that can serve as a basis for the study of other films of this nature.

Palabras clave: documental performativo; estudios visuales; emoción; visualidad; imágenes

Keywords: Performative documentary; Visual studies; Emotion; Visuality; Images 


\section{Introducción}

El cine documental reúne una serie de películas tan diversas entre sí que rebasa continuamente el intento de categorización u organización. El trabajo de Bill Nichols es un ejemplo, en su texto La representación de la realidad (1991) propuso cuatro modos de representación que podrían servir como la base para reconocer y distinguir las piezas documentales: la modalidad expositiva, la observacional, la interactiva y la reflexiva. En un trabajo posterior, Blurred boundaries (1994), agregó una quinta modalidad: la performativa. Esta prioriza la expresividad, la poesía y la retórica por encima de lo referencial, lo informativo y lo fáctico. Años después, en su libro Introduction to documentary (2001) sumó una última: la modalidad poética.

Los aportes de Nichols han significado un antes y un después a la hora de pensar sobre el documental y sus características, por supuesto también es un trabajo polémico que ha sido refutado y muchas veces discutido principalmente por la complejidad de generar una categorización precisa en la que todo el universo de imágenes y relatos sobre lo real tengan cabida (Bruzzi, 200o; Plantinga, 1997). Este proceso de clasificación, y sobre todo el hecho de agregar más modalidades, atiende a las sofisticaciones propias del documental, un tipo de cine libre y mayormente autoral que no deja de sorprender ni de evolucionar. Un cine que exige también, por parte de la teoría, una actualización acorde a su crecimiento.

Rostros y Lugares (Visages Villages, 2017) es un filme realizado por la cineasta Agnès Varda y por el artista y fotógrafo urbano JR. Se trata de una pieza documental que, siguiendo la clasificación de Nichols, se encuentra en la modalidad performativa. Como se explica más adelante, es una obra que no pretende informar, ni convencer casi de nada. Aquí las imágenes son algo más que pruebas referenciales de lo que se describe en el relato. El filme se construye de forma lúdica retratando los puntos de vista de ambos artistas y ofreciendo una reflexión particular sobre el arte, la fotografía, el cine y sus imágenes. El tono es poético y la lógica que lo articula no es persuasiva, sino emotiva, lo que vuelve tentador su análisis. ¿Cómo interpretar una pieza con estas características? ¿Qué 
diferencia estructural hay en una película documental que prioriza emocionar antes que convencer? ¿Puede la emoción estar vinculada con la reflexión? ¿En qué medida?

Por su parte, los estudios visuales son el campo que precisamente está pensando en la complejidad de las imágenes (Català, 2005) y en cómo vincular miradas transdisciplinares para interpretar el arte (Brea, 2005). En este texto se pretende analizar el filme Rostros y Lugares desde esta disciplina junto con los aportes de la teoría documental con la intención de reconocer las particularidades de una pieza performativa que trata temas afines al propio campo de los estudios visuales como lo son el arte, las imágenes y sus visualidades. Esto examinando el tipo de imágenes que se encuentran en el filme e identificando sus funciones al interior del mismo.

\section{Marco conceptual}

\subsection{Estudios Visuales}

Desde hace poco más de una década los estudios visuales han surgido como propuesta de expansión del campo sobre el estudio del arte al proponer una lectura dinámica que desborda los métodos tradicionales de la historia o la estética (del arte) y vinculando una dimensión social, incluso ideológica, a las imágenes - no todas ellas por fuerza de naturaleza artística- que se manifiestan en la cultura contemporánea. Es decir, pensar en los estudios visuales es reconocer un campo en el que las imágenes son el objeto de estudio y la forma de interpretarlas es transdisciplinar, como señala José Luis Brea:

La cuestión es que esa metodología transdisciplinar -tan pragmáticamente indisciplinada- es precisamente la que constituye el caldo de cultivo en que fermentan los estudios visuales, la reivindicación que constituye su propio escenario epistemológico expandido. Puesto que hablamos de prácticas sociales y de comunicación que, más allá de su definición sistematizada en marcos disciplinares cerrados, abarcan y proyectan una multitud de dimensiones significantes (de orden político, social, psicológico, moral, antropológico, económico, perceptual, semiótico...) parece adecuado reclamar un abordaje 
igualmente poliédrico, multidimensional y mestizo por parte de la crítica cultural que ocupándose de ellos aspire a aportar resultados eficientes en su hermenéutica contemporánea (2005, p.13-14).

Pensar las imágenes desde los estudios visuales requiere considerar la complejidad de las mismas, dejar de perpetuar el mito de que una imagen puede leerse como si su significado fuera único, literal y no tuviera más alcance que la traducción a palabras.

Las imágenes, obviamente, no hablan, puesto que no emiten ningún sonido, ni proponen significados de la manera en que lo hacen las palabras o los textos. Eso no quiere decir que no expresen nada, sólo se nos puede ocurrir esto si equiparamos expresión a expresión lingüística. En todo caso, creer que las imágenes hablan es utilizar, como decía, una metáfora para intentar explicar lo que hacen, sin acabar de comprender adecuadamente cuál es esa actividad y cómo funciona (Catalá, 2008, p. 12).

Las imágenes son complejas y están relacionadas con otras imágenes. En ellas, como explica Català (2008) se encuentran cuatro funciones básicas que son: la función informativa, la función comunicativa, la función reflexiva y la función emotiva, lo que significa que estas reproducen, representan, piensan y sienten, tal vez no hacen todo a la vez y muchas veces priorizan una función por encima de otra, pero en su fenomenología están contenidas las cuatro; en palabras del autor:

De esta misma clasificación se desprende de inmediato que difícilmente estas funciones pueden aparecer por separado, aunque, desde una perspectiva estrictamente pragmática, pueden desarrollarse prácticas que privilegien alguna de las funciones sobre las demás.

Además de que las imágenes complejas tienen varias funciones primarias, éstas también están vinculadas a un contexto histórico, social y político que puede llevar a entenderlas como fenómenos sociales y en muchos casos ideológicos, las cuales se interpretan como visualidades específicas (Català, 2008, p.20).

Para autores como Nicholas Mirzoeff, las imágenes, que están cambiando a un ritmo acelerado, provienen de distintos orígenes y se distribuyen sin aparente contención, por lo que se transforman en visualidades específicas, es decir en 
hechos sociales que son vistos - comprendidos- desde un punto de vista colectivo. Estas visualidades son las formas organizadas por el poder y la autoridad. Sin embargo, también pueden contradecirse creando nuevas visualidades o contravisualidades:

la visualidad, que surgió como una táctica militar y más tarde se convirtió en una forma de poder para validar su autoridad. En la vida cotidiana es común para nosotros escuchar a un policía decir frente a un acontecimiento: "No te detengas, no hay nada que ver aquí". Por supuesto que hay algo que ver, ellos lo saben y nosotros también. La pregunta es ¿̇quién tiene derecho a mirar? Cuando exigimos libertad para "ver" cómo está organizado el terreno de lo social creamos una forma de "contravisualidad". El primer cambio que yo observo en la visualidad es que la gente de todo el mundo -desde Egipto y Brasil hasta Nueva York, con el movimiento de Occupy Wall Street-, ha comenzado a reclamar su derecho a mirar y crear "contravisualidades". En la actualidad existe una crisis de visualización y una crisis de autoridad que están directamente relacionadas: si los Estados y los gobernantes buscan recuperar la autoridad entonces tendrán que crear una nueva forma de visualizar (Revista Código, 2013, párrs. 5-6).

Por todo lo anterior, se afirma que los fundamentos básicos de los estudios visuales ponen en primer lugar a las imágenes como objeto complejo y cambiante, con funciones específicas, que además no están aisladas del mundo social que las rodea, por lo que su poder o alcance no es sólo comunicativo o estético, sino también político y social.

\subsection{La modalidad performativa}

El documental performativo es un tipo de cine moderno que prioriza al sujeto por encima del objeto, del mismo modo que pudo observarse en otras artes, por ejemplo, en la fotografía clásica, Henri Cartier Bresson o Robert Dosineau privilegiaban la escena filmada a los pensamientos o deseos del propio fotógrafo, todo lo contrario que las imágenes de Nan Goldin o Nobuyoshi Araki en las que el sujeto y sus afectos fueron centrales a la hora de apretar el obturador, creando así la fotografía moderna. De igual manera, en el documental performativo ya no solo se mira la realidad, sino que se interpela desde un punto de vista subjetivo, tal como explica Nichols: 
Si aplicamos al género documental el marco establecido por Roman Jakobson, con los seis aspectos que serían operativos en toda comunicación (lo expresivo, lo referencial, lo poético, lo retórico, lo fáctico y lo metacomunicativo), veremos claramente que el documental performativo articula un cambio de énfasis, ya que abroga la centralidad del aspecto referencial. Cuando se deja de enfocar el mundo histórico que nos rodea a través de una supuesta ventana, son la expresividad, la poesía y la retórica, en flexible combinación, las que se presentan como las nuevas dominantes -cierto es que el documental ha ostentado dichas cualidades desde Night Mail (1936) o Turksib (1929); lo que queremos subrayar es su función más inédita como dominante organizativa del texto (2001, p. 200).

El referente deja de ser el centro de la película, como se puede observar en casi toda la obra documental de Werner Herzog o de la propia Agnès Varda, ya que no se pueden imaginar sus filmes sin ellos interactuando con los personajes que entrevistan, con las situaciones que provocan o con las reflexiones que suceden precisamente en el encuentro entre el cineasta y el entorno en el que se realiza la película - por supuesto cada uno de ellos con su estilo y su postura ético-estética particular-.

La sorpresa y el azar forma parte de este modo de representación que pretende privilegiar la mirada subjetiva y colocar al cineasta físicamente como parte esencial de la película, como un personaje más, que además de estar presente condiciona conscientemente la escena. Este personaje “director de cine” tiene, como en el performance artístico, carisma y debe contactar con el espectador (Gómez-Peña, 2005).

Reconocer en Rostros y Lugares las características del documental performativo permite, por lo tanto, colocar el análisis en el terreno de lo subjetivo, en el que el director-artista está presente y en el que su mirada hilvana la historia que se cuenta, dejando fuera las pretensiones de objetividad y de información para priorizar el desarrollo emotivo y reflexivo de la realidad. 


\section{La ruta metodológica}

Según la relevancia que los estudios visuales brindan a las imágenes, sus funciones y sus visualidades, así como a las características de emoción y participación, propias de la modalidad performativa, el análisis se organizará de la siguiente manera: en primer lugar, se describirán las miradas, es decir, el punto de vista desde el cual se aproximan los artistas de Rostros y Lugares a eso que registran - tomando en cuenta que ellos son parte del performance-; en segundo lugar, se revisarán las reglas del juego con las que los artistas intervienen en los pueblos y con las que ellos determinan los momentos del documental. Por último, se separará el análisis en cuatro tipos de imágenes que constituyen este documental $-\mathrm{y}$ tal vez algún otro performativo-, las cuales son: imágenes instalación, imágenes introspección, imágenes ausencia e imágenes reproducción.

Se entiende por tipo de imágenes el ejercicio taxonómico recuperado de los aportes de Guilles Deleuze en sus textos sobre cine: La imagen-movimiento (1984) y la imagen-tiempo (2004). En ellos el filósofo francés, cuando se refiere a imágenes, está hablando de ideas visuales, audiovisuales, significantes y referenciales.

\section{Las miradas}

El cine documental de Varda está íntimamente ligado a la fotografía. Su registro cinematográfico muchas veces atiende a los mismos principios que la imagen fija, como pueden ser la búsqueda del instante, el retrato y la composición clásica. De hecho, para ella van siempre de la mano, como le explica a Christa Blümlinger (2011) en una entrevista:

La fotografía nunca ha dejado de enseñarme cómo hacer cine. Y el cine me recuerda en todo momento que para nada se rueda el movimiento, ya que toda imagen se vuelve recuerdo y todo recuerdo se petrifica y se fija. En toda fotografía existe la suspensión de un movimiento que finalmente es un rechazo del movimiento. El movimiento está implícito. En toda película existe la voluntad de capturar la vida en movimiento y de rechazar la vida inmóvil. Pero la imagen fija 
está implícita en una película, como la amenaza de una avería del motor, como la muerte que acecha (p.75).

Otro elemento importante en su cine documental es su propia biografía, en sus filmes se muestran historias personales, se observan sus pasiones y sus tristezas. Por ejemplo, la pérdida de su esposo Jaques Demy. Ella hace de su biografía un tema más de sus películas como se puede apreciar en Las playas de Agnès (Les plages d'Agnès, Agnès Varda, 2008; Rice, 2011). Se asume como fotógrafa, como viuda y como recolectora de imágenes, esto último atiende al hecho de dejarse sorprender por las historias que para ella están en el camino, solo hace falta ir a buscarlas, como dejó claro en Los cosechadores y yo (Les glaneurs et la glaneuse, Agnès Varda, 2000), un filme que revela, entre otras cosas, su manera de grabar, de viajar, de envejecer y de crear (Merino, 2019).

Por su parte, la obra de JR ha dado mucho de qué hablar en el mundo del arte por utilizar la calle como lienzo y por volver a los extraños un acontecimiento. Su trabajo consiste principalmente en tomar fotografías en blanco y negro, ampliarlas en gran formato y pegarlas en los muros a manera de protesta. En todos sus proyectos se hace evidente su preocupación por temas sociales, así como por dar visibilidad a aquellos que no la tienen en condiciones políticas particulares.

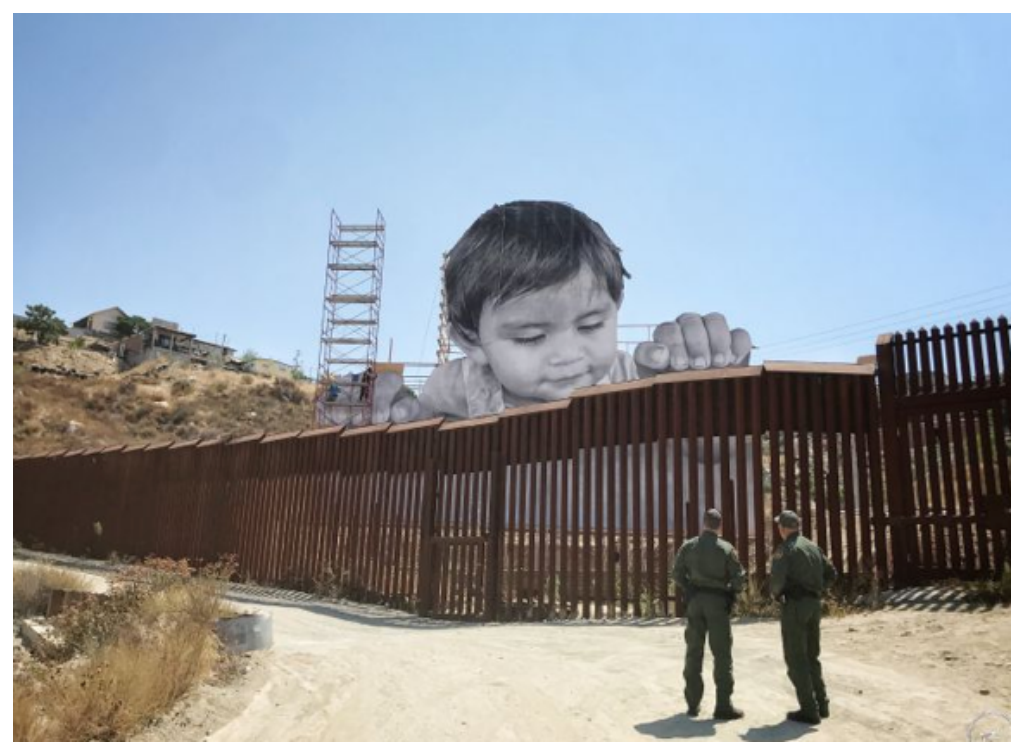

F1. JR en Tecate (Jean René [JR], 2017) 


\subsection{El proyecto juntos}

Rostros y Lugares cuenta la historia de cómo JR busca a Agnès Varda para hacer una película, en ella los dos artistas harán fotografías recorriendo algunos pueblos de Francia para intercambiar experiencias sobre su trabajo y para crear piezas nuevas a manera de intervención callejera en los lugares que van visitando y/o reconociendo juntos.

La película se organiza como road movie, cada parada podría equivaler a una secuencia distinta en la que se trabaja para montar una obra - se toman fotografías en blanco y negro, de gran formato y se pegan en las paredes de los distintos lugares-, pero también cada que el filme avanza, se profundiza en el conocimiento de los artistas. Ellos intercambian opiniones sobre lo que ven y sobre quiénes son, dejando que temas como la memoria, la vejez, la juventud, la pérdida, el anonimato, la amistad, la muerte, entre otros, se cuelen en el viaje, dando como resultado una película más compleja y emotiva de lo que aparentemente puede leerse.

Las reglas del juego son claras tanto para los artistas como para el espectador, en una camioneta adecuada como cámara se harán las instantáneas y ambos participarán del proceso creativo, ya sea haciendo nuevas imágenes o reapropiándose de otras que ya existan, para luego invadir con ellas las paredes. Los lugares deberán ser rurales, pueblos pequeños que vayan descubriendo o revisitando juntos. Las grandes ciudades quedan fuera del itinerario.

Como resultado de este ejercicio, en el filme se reconocen principalmente cuatro tipos de imágenes: las instalación, que son propiamente las fotografías de gran formato con las que intervienen los espacios; las introspección, que son secuencias, escenas o planos en los que los artistas se preguntan por situaciones personales -en ellos casi siempre están de espaldas a la cámara (un gesto muy godariano) - ; las ausencia, en las que se evoca algo o a alguien que ya no está la tumba de Henri Cartier Bresson, la casa de Jean Luc Godard, la vista perdida, etc.-. Y, por último, las reproducciones, que son imágenes de las imágenes que viralizan las piezas hechas para el documental y las inmortalizan en las redes 
sociales para multiplicar y conservar en formato digital copias de las instalaciones.

\subsection{Las imágenes-instalación}

A lo largo del documental, Agnès Varda y JR intervienen 12 espacios con sus fotografías en gran formato. A continuación, se hace una breve descripción de ellas:

1. Retratan a los habitantes de L'Escale mordiendo un baguette para dar la sensación de estar todos comiendo del mismo pan.

2. En el norte visitan una zona minera casi deshabitada. En las fachadas de las casas que habían sido de mineros montan varios retratos antiguos de ellos extraídos de postales viejas que conservaba Varda. También en la casa de Jeanine Carpentier - la única que todavía habita la calle - colocan una fotografía suya.

3. En Vexin, otro pueblo, encuentran un cobertizo e inmortalizan a Clemens Dungern el único trabajador con un retrato agigantado. Para ello utilizan el equipo con el que él trabaja solo la tierra.

4. En el sur deciden utilizar un retrato antiguo de una pareja: Emilie y Emile, y la colocan en la pared de la casa de sus familiares: Marie Dolivet y Jean-Paul Beaujon. En el mismo pueblo retratan a Nathalie Schleemauf, una camarera con una sombrilla antigua y emplazan su imagen en un edificio con balcón, haciendo de ella la celebridad de verano.

5. En la Fábrica hacen dos instalaciones, la primera es una fotografía de los trabajadores alzando las manos en dos grupos, de tal forma que cuando la montan pareciera que los obreros se quieren tocar. En ese mismo espacio decoran una torre de agua con peces agigantados que rodean el tanque.

6. En el pueblo casi abandonado de Pirou invitan a los vecinos a un picnic y hacen retratos de todos ellos para tapizar las paredes y dar vida al espacio fantasma.

7. En el sur, Agnès retrata a Vincent Gils, su antiguo cartero y colocan su imagen en la fachada de su casa. 
8. En otro pueblo hacen una pieza juntando retratos con fondo de tela de cuadros como si se tratara de una gran manta de picnic. Entre los fotografiados está Pony, un hombre jubilado de 75 años que vive en armonía haciendo arte con materiales encontrados.

9. La siguiente instalación es el retrato de una cabra con cuernos en la pared de un granero, ya que en ese mismo pueblo hay quienes piensan que para hacer más productivos a estos animales hay que quemarles los cuernos, mientras que otros defienden el respeto por los animales y los dejan crecer con ellos.

10. En las playas de Normandía deciden colocar una antigua fotografía que tomó Agnès Varda años atrás a su amigo Guy Bourdin. Lo hacen sobre un bunker que se mantiene en la playa desde la guerra. La imagen permanece sobre el bunker un solo día porque al subir la marea, ésta la borra.

11. En el puerto Le Havre retratan a tres mujeres: Nathalie, Sophie y Denis, esposas de trabajadores del puerto y colocan las imágenes en una pila de contenedores, dando presencia a las mujeres, generalmente invisibles en ese espacio de hombres.

12. Para la última pieza, JR fotografía los ojos y los pies de Agnès para colocarlos sobre camiones y pipas en movimiento.

Sin duda cada una de estas piezas puede ser analizada desde los estudios visuales como obra única que plantea una inserción, una intervención y una visualidad. Por ejemplo, en el pueblo minero los artistas recolectan postales antiguas y además hacen una entrevista a la única mujer que habita la fila de casas en las que años atrás vivían los mineros. El proceso de inserción permite conocer a Jeanine e identificar en su historia una declaración de principios, una lucha silenciosa por mantener viva su calle y con ello vivo el recuerdo de los hombres que trabajaron las minas. Los personajes extraídos de las postales serán parte de la intervención, la idea es volver a poblar la calle, pero sobre todo recordar su trabajo y darles visibilidad. Colocar a Jeanine al lado de ellos significa reconocer su causa, darle sentido a su reticencia por no abandonar el pasado, así como el legado de su abuelo. En términos de visualidad, la pieza nos invita a pensar en los 
oficios olvidados y en las pocas personas que se dedican a la conservación y al reconocimiento de su valor histórico y social. La obra en sí provoca una contravisualidad porque saca a la luz aquello que está a punto de desaparecer.
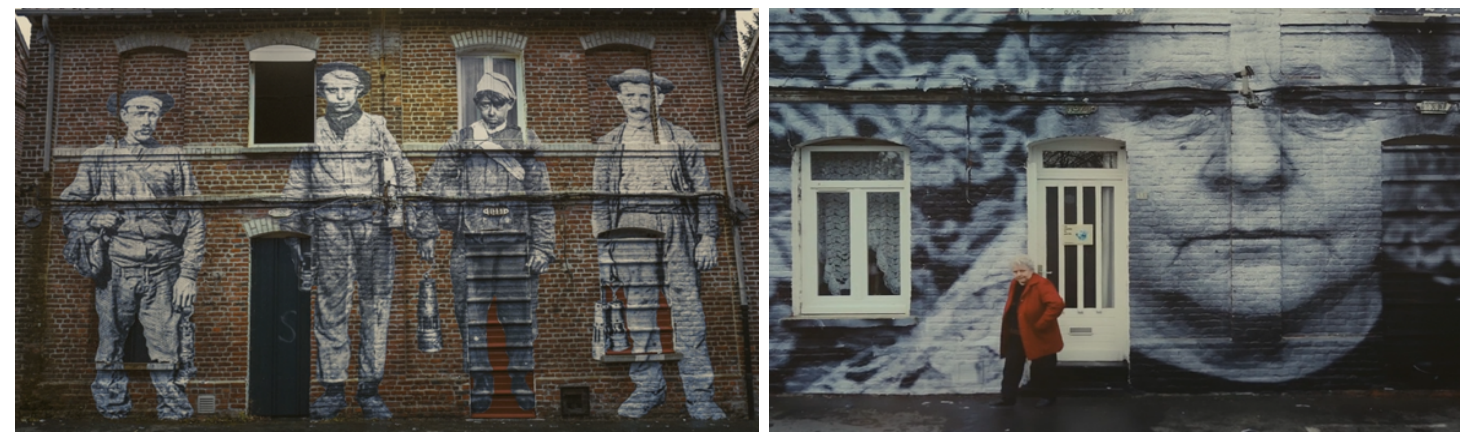

F2. Mineros y Jeanine (Rostros y Lugares, 2017)

En el caso de las mujeres del puerto, el trabajo de inserción se hace de la siguiente manera: Agnès conoce a los trabajadores del puerto con quienes JR había realizado un proyecto anterior y cuando lo hace les pregunta por las mujeres del lugar, por lo que ellos le presentan a sus esposas, una de ellas incluso trabaja como conductora de camiones en el puerto - un trabajo aparentemente exclusivo para hombres-. Los artistas retratan a las tres mujeres y colocan sus enormes fotografías sobre una pila de contenedores, dejando claro que en ese mundo de hombres las mujeres también están presentes. La intervención visualiza a las mujeres del lugar mostrándolas como seres fuertes, capaces y presentes. Se trata de una contravisualialidad puesto que las imágenes proponen una nueva manera de ver los espacios supuestamente masculinos, reconociendo el papel de las mujeres, su presencia y su relevancia. Ellas siempre han sido un tema en la filmografía de Varda - como se puede apreciar en Cleo de 5 a 7 (Cléo de 5 à 7 , 1962), Una canta, la otra no (L'une chante, l'autre pas, 1976), Sin techo ni ley (Sans toit ni loi, 1985), etc-.

En cada pieza se reproduce el mismo proceso: inserción, intervención y contravisualidad porque hay un conocimiento de las personas previo a realizar los retratos, porque cada retrato colocado propone un discurso específico que pretende interpelar a quien lo mira de forma particular y porque muchas veces ese ejercicio de visualización provoca una contravisualidad: ver a los obreros de la Fábrica casi tocarse las manos en señal de unidad y pertenencia, ver a la cabra 
con cuernos en respuesta al respeto animal, comer todos del mismo pan. Son imágenes con una carga fuertemente metafórica, una propuesta política de mirar a los invisibles, de recuperar y honrar su historia, de dar una opinión sobre lo que debe salir del anonimato y ser observado. El arte en los muros desde el muralismo mexicano hasta el street art conlleva ese gesto pedagógico, político y revolucionario, de ahí el poder de estas imágenes-intervención. Un tema que Varda ya había tratado en Mur murs (1981) un filme sobre los murales de la ciudad de Los Ángeles, California.

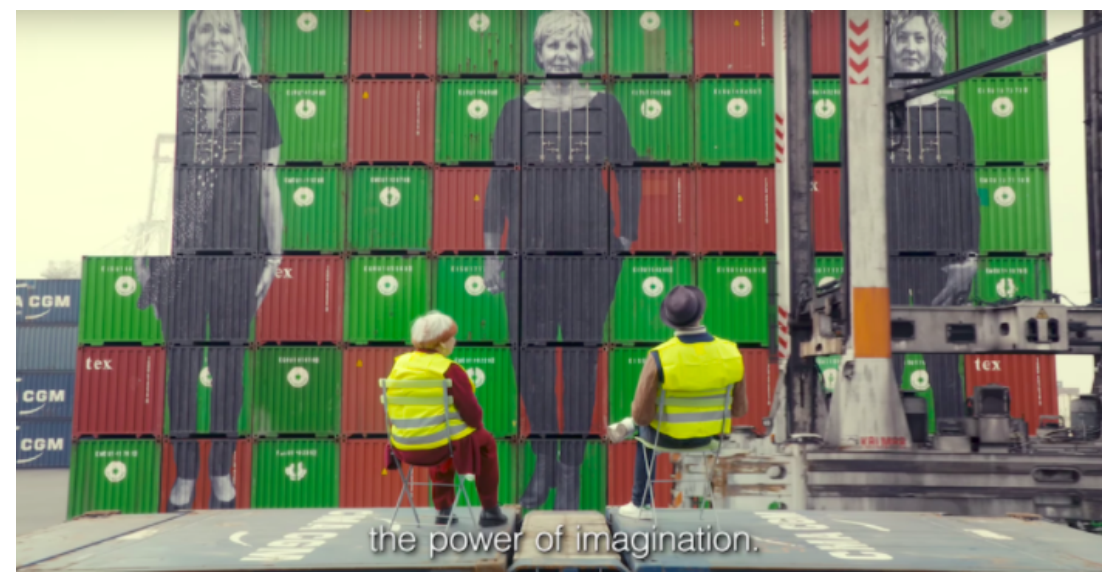

F3. Las mujeres del puerto (Rostros y Lugares, 2017)

\subsection{Imágenes-introspección}

A lo largo del filme, además del viaje y de las intervenciones que hacen en los distintos pueblos, Agnès y JR también se detienen a conocerse, no sólo como artistas, sino como personas. Estas escenas son tal vez las más conmovedoras del documental, las que permiten argumentar su carácter performativo y ver la función emotiva de las imágenes por encima de las otras.

La función emotiva en la modalidad performativa debe entenderse como una forma de invitar al espectador a sentir algo, como afirma Greg M. Smith:

Greg M. Smith (2003) [...] resume con bastante precisión las virtudes del enfoque cognitivo cuando afirma que el estudio de las emociones fílmicas ha de abordar in extenso todos los mecanismos que la provocan, desde la iluminación a las convenciones de género, pasando por la puesta en escena, la gestualidad de los actores, la gestión de la cámara, el sonido, la música, los recursos narrativos, etc. De forma muy pertinente, Greg M. Smith engloba bajo el concepto de estilo todos 
estos factores o agentes en los que pivotan las reacciones afectivas del espectador cinematográfico, y propone un abordaje integral que marca distancias respecto a algunos de sus correligionarios (Noël Carroll, Ed Tan y Torben Grodal son aludidos explícitamente) a los que imputa aproximaciones más selectivas y parciales. A su entender, la película no hace sentir a la gente ("Films do not 'make' people feel"), sino que les invita a sentir de determinada manera, y cada cual aceptar o rechazar el ofrecimiento ("film extend an invitation to feel in particular way. Individuals can accept o reject the invitation”). Esta invitación no es única, sino que se despliega a lo largo de la película en una sucesión de exhortaciones que el espectador acepta o rechaza a cada paso (Smith en Zumalde, p. 338).

En la película se presentan estas invitaciones en todo el documental y en ocasiones surgen como respuesta a algún tema o situación que las intervenciones hayan suscitado. Por ejemplo, después de conocer a Chérence (el hombre del granero), quien les explica cómo se ha reducido de forma significativa el número de trabajadores del campo debido a la tecnología, al grado que él trabaja sólo. Les confiesa que eso no le importa porque después de su jornada de trabajo llega a casa con su familia y se siente acompañado. En la escena siguiente los artistas se encuentran de espalda a la cámara, sentados en una banca a la orilla del lago y se preguntan entre ellos quién los espera en casa.

Otro ejemplo es la secuencia que cuenta el tema de la enfermedad que Agnès comienza a tener en los ojos. En imágenes documentales se observa a la cineasta en el quirófano cuando va a que le inyecten los ojos. En una escena subsecuente, JR organiza una performance para ilustrar cómo mira Agnès con su enfermedad. Por último, hablan de ello, como se muestra en el siguiente fragmento:

-JR: Con que ves borroso y, ¿así eres feliz?

-Agnès: qué me preguntas si tú miras en blanco y negro.

Esta secuencia tiene un contenido emotivo muy claro: la cineasta está perdiendo la vista, el paso del tiempo impacta en su cuerpo. Sin embargo, parece que eso no es un problema para poder mirar y esta idea -tan presente en los estudios visuales- lleva la reflexión sobre mirar más allá de la función óptica de ver. Varda afirma que mirar es un gesto más complejo que no se limita al acto de percibir 
imágenes, un gesto que implica al sujeto que mira y cómo este recibe y transforma el referente en algo más, en su caso: en arte.

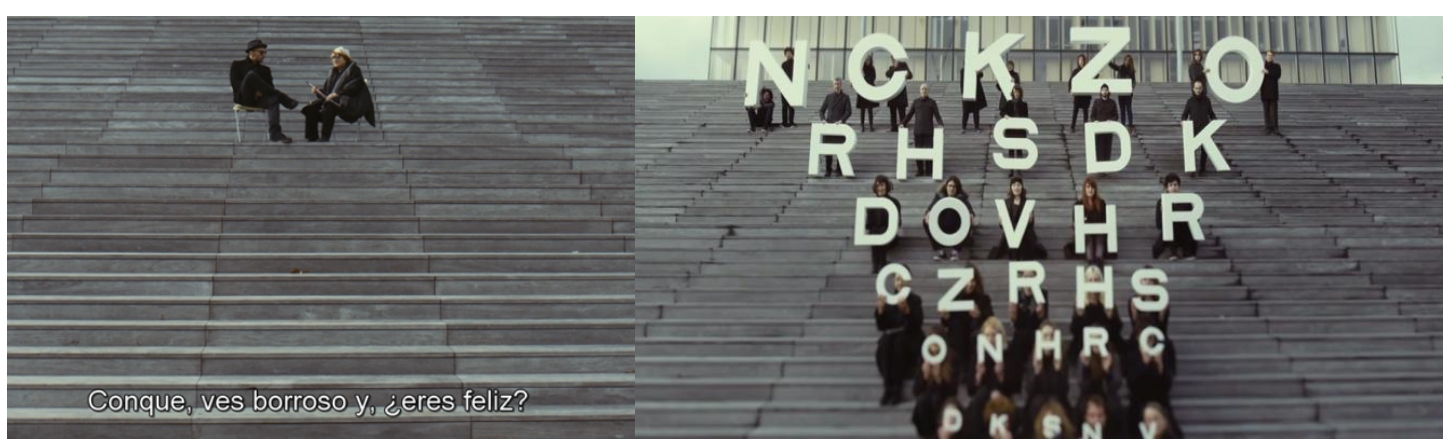

F4. JR, Agnès y letras en movimiento, (Rostros y Lugares, 2017)

En ese mismo sentido, durante el filme la diferencia de edad entre los artistas se convierte en un tema transversal y se muestra con gestos sutiles, pero significativos. Por ejemplo, cuando realizan la pieza número dos en la Fábrica, pretenden subir a verla desde lo alto del edificio continuo a la pipa donde colocaron los pescados agigantados y ella no puede subir, y mucho menos a la velocidad que lo hace él. Pero esto no es un problema, ni se retrata de forma lastimera, es una realidad que hace evidente por qué miran diferente los artistas, ya que él entiende el mundo desde los 33 y ella desde los 88 , sin más.

\subsection{Imágenes-ausencia}

En el transcurso del filme, además de las instalaciones y los momentos en que los artistas hablan entre ellos sobre sí mismos, hay otro tipo de imágenes que constituyen el documental, éstas funcionan como late motiv y son las que hacen alusión a los artistas que ya no están (Cartier Bresson, Gay Bourdin) o que no aparecen en la película (Jean-Luc Godard). Desde el inicio de la película, Agnès Varda le dice a JR que le recuerda a su amigo Jean-Luc, por llevar gafas oscuras, entre otras cosas y desde esa declaración, el recuerdo de su amigo aparecerá como parte de la conversación entre ellos, así como en dos escenas particulares: la primera cuando recrean la escena de Banda aparte (Bande à part, Jean-Luc Godard, 1964) recorriendo los pasillos del Louvre en silla de ruedas y la segunda, cuando deciden visitar al cineasta en su casa y éste no les abre la puerta. 
Godard se convierte en una metáfora de lo que fue y ya no es: juventud, amistad, y el propio cine, ese cine que deconstruyeron los modernos y que ahora sufre otras fracturas. Un cine que sólo conocía una gran pantalla y que no era parte de redes sociales comentadas y activas. Godard no le abre la puerta a su amiga, tal vez para no entrometerse en su película, tal vez para no interrumpir la nueva amistad de Agnès, tal vez para seguir siendo el cineasta caprichoso que ha sido siempre, tal vez para negar nuevamente un happy end. En el filme la ausencia se convertirá en metáfora de todo lo que ha dejado atrás el paso del tiempo y que sin duda ha condicionado la forma de mirar y reflexionar a través de las imágenes de los dos artistas. Juntos fotografían el mundo para no olvidarlo, porque coinciden en que las imágenes inmortalizan, congelan, suspenden y perpetúan.

\subsection{Imágenes-reproducción}

Las imágenes-reproducción son aquellas que se hacen todo el tiempo durante la película para inmortalizar las obras, algunas de ellas son realizadas por los propios fotógrafos quienes posan frente a las piezas, como los retratos que hace JR de Agnès frente a la cabra con cuernos. La relevancia de estas imágenes radica en la memoria del proyecto, puesto que, como las fotografías están colocadas en muros al exterior, es posible que con el tiempo desaparezcan. Es un arte efímero que las instantáneas digitales logran perpetuar.

Otro tipo de imágenes reproducción son las fotografías que los habitantes de los pueblos hacen de los retratos, incluso de sus propios retratos, generalmente con sus teléfonos, y que casi de inmediato suben a las redes sociales, expandiendo con este gesto los alcances del documental. Son imágenes que cierran el ciclo de la intervención porque difunden las piezas a otros espacios y porque se suman al ejercicio de dar visibilidad a los habitantes anónimos retratados, incluso de convertirlos en celebridades.

Estas imágenes están presentes en todos los lugares y tienen un carácter reflexivo debido a que hacen evidente una época y un comportamiento social ante ellas. Por ejemplo, los familiares de Emilie y Emili se hacen un selfie frente a la fotografía de sus antepasados y se explican uno al otro que la subirán a Facebook por la noche, porque un sobrino suyo ya les enseñó cómo hacerlo. Dos elementos 
resultan relevantes en este diálogo al parecer inocuo, en primer lugar, la relevancia del selfie, que como describe Mirzoeff es la firma de la época:

El selfie describe el drama de nuestra propia representación cotidiana de nosotros mismos en tensión con nuestras emociones internas, que no siempre podemos expresar como deseamos. En cada etapa de expansión del autorretrato, cada vez más gente ha sido capaz de representarse a sí misma. En la actualidad, la mayoría juvenil, urbana y conectada ha reescrito la historia del autorretrato, convirtiendo el selfie en la primera firma visual de la nueva era (2016, p.37).

Y, en segundo lugar, la edad de los sujetos, puesto que en otras escenas gente más joven, incluso niños - como los hijos de la camarera con sombrilla- hacen el selfie y lo suben inmediatamente a una red social, no necesitan esperar a la noche para concentrarse.

\section{Conclusiones}

Rostros y Lugares es un documental performativo que utiliza la emoción -la mayoría de las veces creada por los realizadores que montan el performance para la cámara invitando al espectador a jugar su juego- para crear una reflexión mayor o extendida a los acontecimientos que se muestran. Como se observó en sus cuatro tipos de imágenes, hay una tensión entre los elementos (funciones) emotivos y los reflexivos. En las imágenes-intervención esto sucede de manera clara, ya que todas las piezas con las que intervienen los espacios son una forma de arte contundente y sintético que interpela directamente a quien lo mira. Estas fotografías en blanco y negro que rescatan sujetos y/o situaciones anónimas producen una contravisualidad, es decir una propuesta política de reivindicación y reconocimiento del otro. Emocionan y hacen pensar en un tema puntual.

Las imágenes-introspección traducen esta tensión cuando la llevan de lo personal a lo universal. Los temas por los que se preguntan Varda y JR son de carácter humanístico, por lo que tienen resonancias directas en el espectador, quien seguro también envejecerá, amará, recordará u olvidará. 
Por su parte, las imágenes-ausencia son las encargadas de la memoria y ello implica una emoción nostálgica. El pasado ya no está, pero recordar, recrear o revisitar permite traer fragmentos de él, posibilita sentir, pensar o reflexionar en sus huellas.

Las imágenes-reproducción —que, por supuesto, llevan en el nombre los ecos del trabajo de Benjamin- son las imágenes digitales que trascienden el documental al expandir su relato a otros medios y que con este ejercicio reflejan una época y una forma social de pensar las imágenes. Son contemporáneas y emotivas en el sentido de que sirven de marca de un momento histórico particular.

Estas cuatro categorías se construyeron a partir de los aportes de los estudios visuales y de la teoría documental, y tal vez podrían utilizarse como modelo para interpretar otras piezas documentales que, al igual que Rostros y Lugares, prioricen la emoción a la persuasión, es decir, que construyan una nueva retórica afectiva de la imagen.

También es verdad que la obra de estos dos artistas tendrá estas particularidades y que Rostros y Lugares no es la única pieza que empleé la emoción, pero resulta un cruce significativo de miradas que sintetizan una forma de trabajar y de entender el mundo muy particular.

\section{Referencias bibliográficas}

Blümlinger, C. (2011). De la fotografía al cine y viceversa. L'Atalante. Revista de Estudios Cinematográficos, 12, 70-77.

Brea, J. (2005). Estética, Historia del Arte, Estudios Visuales. Estudios Visuales. Ensayo, teoría y crítica de la cultura visual y el arte contemporáneo, 3, 8-25.

Bruzzi, S. (2000). New Documentary: A Critical Introduction. Londres: Routledge.

Català, J. (2005). La imagen compleja: la fenomenología de las imágenes en la era de la cultura visual. Barcelona: Universidad Autónoma de Barcelona.

Català, J. (2008). La forma de lo real. Introducción a los estudios visuales. Barcelona: UOC.

Deleuze, G. (1984). La imagen-movimiento. Barcelona: Paidós. 
Deleuze, G. (2004). La imagen-tiempo. Barcelona: Paidós.

Entrevista con Nicholas Mirzoeff: Visualidad, contravisualidad e imagen digital. (26 de julio de 2013). Revista Código. Recuperado de https://revistacodigo.com/arte/entrevista-con-nicholas-mirzoeff/

Godard, J. (1964). Bande à part. Francia: Columbia Pictures.

Gómez-Peña, G. (2005). En defensa del arte del performance. Horizontes Antropológicos, 24, 199-226.

Merino, I. (2019). Agnès Varda. Espigadora de realidades y ensueños. Donostia San Sebastián: Donostia Kultura.

Mirzoeff, N. (2016). Cómo ver el mundo: Una nueva introducción a la cultura visual. Barcelona: Paidós.

Nichols, B. (1991). La representación de la realidad. Barcelona: Paidós.

Nichols, B. (1994). Blurred Boundaries: Questions of Meaning in Contemporary Culture. Indianapolis: Indiana University Press.

Nichols, B. (2001). Introduction to Documentary. Indianapolis: Indiana University Press.

Plantinga, C. (1997). Rhetoric and Representation in Nonfiction film. Cambridge: Chapbook Press.

Rice, S. (2011). El hilo de Ariadna: en las Playas que son Agnès Varda. L'Atalante. Revista De Estudios Cinematográficos, 12, 64-69.

Varda, A. (1962). Cléo de 5 à 7. Francia: Ciné Tamaris, Rome Paris Films.

Varda, A. (1976). L'une chante, l'autre pas. Francia: Ciné Tamaris.

Varda, A. (1981). Mur murs. Francia: Ciné Tamaris.

Varda, A. (1985). Sans toit ni loi. Francia: Films A2, Ciné Tamaris, Centre Méditerranéen de Création Cinématographique, Film 4, Ministère de la Culture.

Varda, A. (2000). Les glaneurs et la glaneuse. Francia: Ciné Tamaris.

Varda, A. (2008). Les Plages d'Agnès. Francia: Ciné Tamaris, France 2.

Varda, A. y Jean René (2017). Visages Villages. Francia: Ciné Tamaris, Arte France Cinéma, Social Animals.

Zumalde, I. (2011). La emoción fílmica. Un análisis comparativo de las teorías cinematográficas. Revista Latina de Comunicación Social, 66, 326-349. 